\title{
Employability Skills: Malaysian Employers Perspectives
}

\begin{abstract}
The purpose of this paper is to present findings of employability skills expected by Malaysian employers when hiring new graduates. Data were collected by analyzing the appointment section of Saturday issues of a major newspaper in Malaysia. The analysis showed 29 employability skills that were repeatedly mentioned by many employers. Among the skills are communication skills, interpersonal, personality skills, leadership qualities, computer literacy, planning, management, teamwork, motivation, logical and analytical skills, independent, resourceful, and knowledgeable, fast learner, adaptability, honesty, integrity and commitment, result oriented, dynamic, enthusiasm, aggressive, energetic, professionalism, problem-solving skills, able to work under pressure (tight schedule) with minimum supervision, discipline, negotiation skills, supervision, presentation (report writing) skills, proactive, initiative, and creative, accountability, maturity, responsibility, strategic thinking abilities, initiative.
\end{abstract}

Keyword: Employability Skills, Soft Skills, Generic Skills, Malaysian Employers 